\title{
In Vitro Effects of Bisphenol F on Antioxidant \\ System Indicators in the Isolated Hepatocytes of Rainbow Trout (Oncorhyncus mykiss)
}

Handan Aykut

Yuzuncu Yil University: Van Yuzuncu Yil Universitesi

Burak Kaptaner ( $\nabla$ bkaptaner@yyu.edu.tr)

Van Yuzuncu Yil University https://orcid.org/0000-0003-2366-6756

\section{Research Article}

Keywords: Bisphenol F, Oncorhyncus mykiss, Cultured fish hepatocytes, Cytotoxicity, Antioxidant system indicators

Posted Date: February 10th, 2021

DOI: https://doi.org/10.21203/rs.3.rs-176884/v1

License: (c) (i) This work is licensed under a Creative Commons Attribution 4.0 International License.

Read Full License

Version of Record: A version of this preprint was published at Molecular Biology Reports on March 31 st, 2021. See the published version at https://doi.org/10.1007/s11033-021-06310-3. 


\section{Abstract}

Bisphenol F (BPF) has been used frequently in the plastics industry and the production of daily consumer products as an alternative to bisphenol A (BPA). It was aimed herein to determine the cytotoxic effects of BPF on hepatocytes isolated from the liver of rainbow trout (Oncorhyncus mykiss) using lactate dehydrogenase (LDH) assay and antioxidant defence system indicators. The cultured hepatocytes were exposed to seven concentrations $(0,15.63,31.25,62.50,125,250$, and $500 \mu \mathrm{M})$ of BPF for $24 \mathrm{~h}$. According to the LDH assay, the percentage of cytotoxicity was increased dose dependently in the cells. The malondialdehyde content, which is indicative of lipid peroxidation, was increased significantly at BPF concentrations between 15.63 and $250 \mu \mathrm{M}$, whereas it remained unchanged with a concentration of 500 $\mu \mathrm{M}$. The activities of superoxide dismutase were increased, while those of catalase were decreased with all of the BPF concentrations. Elevated levels of reduced glutathione content were determined with BPF concentrations between 15.63 and $250 \mu \mathrm{M}$, but decreased significantly with a concentration of $500 \mu \mathrm{M}$. Significant increases in the activities of the glutathione peroxidase were found in hepatocytes treated with BPF at concentrations of 31.25 to $500 \mu \mathrm{M}$. GST activity was only significantly increased with a BPF concentration of $250 \mu \mathrm{M}$. The results showed that the toxic mechanism of BPF was mainly based on cell membrane damage and oxidative stress, which have an influence on antioxidant defences. Therefore, BPF was reconsidered as a safe alternative instead of BPA in the manufacturing of industrial or daily products.

\section{Introduction}

Bisphenols are a chemical class known as diphenylmethanes that contain two hdroxyphenyl groups. Among this chemical group, bisphenol A (BPA) is the most commonly used chemical in the plastics industry and consumer product manufacturing. Nowadays, it is well-known from scientific reports over the last two decades that BPA is an endocrine-disrupting chemical that possesses suspected harmful effects on human and environmental health, such as carcinogenesis, obesity, diabetes, and behavioural, developmental, and reproductive abnormalities. Therefore, scientists and authorities have instructed manufacturers to restrict the utilization of BPA as they search for safer alternatives [1]. Eventually, a gradual replacement of BPA along with its analogues or derivatives, such as bisphenol AF (BPAF), bisphenol $F(B P F)$, bisphenol S (BPS), tetrabromobisphenol A, and tetrachlorobisphenol A was found. Due to its more biodegradable features under anaerobic and aerobic conditions, and because it has lower environmental risks when compared to BPA, BPF has been frequently preferred in epoxy resin, plastic, coating, varnish, dental sealant, and food packaging production. On the other hand, BPF has been found in the paper, personal care, and food products used in daily life [2]. It has also been determined at an average concentration of $0.054 \mu \mathrm{g} / \mathrm{g}$ in household dust [3], and in surface waters, sediments, and effluents from sewage [4]. Recent studies have reported that BPA analogues, including BPF, have caused developmental abnormalities in the reproductive tissues of male rats, altering their hormonal balance and antioxidant defences [5]. Similar to BPA, the genotoxic, immunotoxic, and neurotoxic potentials of its analogues have been reported in some experimental studies over last decade [6-8]. 
Fish constitute an important ring of the food chain for humans and other higher organisms, and they might be at risk of exposure to BPA analogues, which are distributed widely in aquatic environments. The detection of BPF was reported in the muscle and liver tissues of some species from the North East Atlantic Ocean [9]. Recent experimental studies have shown that BPF led to different types of harmful effects in fish. For example, it was reported that BPF altered gonad histology in zebrafish (Danio rerio) and impaired hormonal balance by changing the gene expression along the hypothalamic-pituitarygonadal axis [10]. BPF has also led to the developmental defects, such as decreased heart rate, inhibited spontaneous movement, and spinal deformation, by downregulating the related genes in zebrafish at environmentally-relevant concentrations [11]. BPF has been reported to change the transcription of genes related to thyroid development, hormone transport and metabolism, and impaired thyroid hormone balance and function in developing zebrafish embryos/larvae [12]. Hence, BPF is a suspected alternative to BPA, although further studies are necessary to discern its hazardous impacts due to the limited data available in the literature.

Environmental pollutants are capable of increasing the levels of reactive oxygen species (ROS) in cells, which results in oxidative stress. As a status of the imbalance between antioxidant defences and the generation of ROS, oxidative stress causes deleterious effects that are damaging to cellular membrane lipids, proteins, or DNA, and consequently, a loss of function or death occurs in the cells. Lipid peroxidation is a significant indicator of oxidative damage that can be induced by environmental compounds [13]. Fish possess antioxidant defence systems, both enzymatic and nonenzymatic, that help to protect them against oxidative stress and respond to environmental pollutants via antioxidant enzymes, such as catalase (CAT), glutathione peroxidase (GPx), glutathione S-transferase (GST), and superoxide dismutase (SOD), as well as nonenzymatic enzymes, such as glutathione (GSH). These mentioned members of the antioxidant defence system have been frequently selected as oxidative stress biomarkers that are related to xenobiotics in fish [14]. Toxicity studies in in vitro have shown that BPF increased ROS levels, induced lipid peroxidation, and modified antioxidant enzyme activity in different cell types, such as human erythrocytes [15], and RWPE-1 cells [16].

Isolated fish hepatocytes have been used as a suitable model or screening tool to analyse the cytotoxic impacts and oxidative stress-inducing potential of environmental chemicals [17]. Rainbow trout (Oncorhyncus mykiss) is a test animal that has been recommended by the Organisation for Economic Cooperation and Development in toxicological studies for testing chemicals [18]. As far as is known, to date, no studies have been performed to assess the cytotoxic and oxidative stress impacts of BPF, which is an analogue of BPA, using isolated rainbow trout hepatocytes. The aim herein was to evaluate the effects of BPF on selected antioxidant defence system indicators of oxidative stress, such as the GSH content and malondialdehyde (MDA) levels, as an indicator of lipid peroxidation, as well as antioxidant enzyme activities, such as SOD, CAT, GPx, and GST.

\section{Material And Methods}

\section{Fish}


The fish used in this study comprised 3 female, juvenile rainbow trout (Oncorhyncus mykiss), weighing approximately $300 \mathrm{~g}$, which were purchased from a rainbow trout farm in Van, Turkey. The fish were anesthetized with 2-phenoxyethanol $(0.32 \mathrm{~mL} / \mathrm{L})$ before hepatocyte isolation.

\section{Preparation of the Isolated Hepatocytes}

Isolation of the hepatocytes from the fish was performed according to the method of Mortensen et al. [19], with some modifications. All instruments and solutions were sterilized prior to the procedures. In brief, the livers of the fish were aseptically dissected and placed into a Petri dish that contained cold $\mathrm{Ca}^{2+}$ free solution-I, comprising $7.14 \mathrm{~g} / \mathrm{L}$ of $\mathrm{NaCl}, 0.36 \mathrm{~g} / \mathrm{L}$ of $\mathrm{KCl}, 0.15 \mathrm{~g} / \mathrm{L}$ of $\mathrm{MgSO}_{4}, 1.6 \mathrm{~g} / \mathrm{L}$ of $\mathrm{Na}_{2} \mathrm{HPO}_{4}, 0.4$ $\mathrm{g} / \mathrm{L}$ of $\mathrm{NaH}_{2} \mathrm{HPO}_{4}, 0.31 \mathrm{~g} / \mathrm{L}$ of $\mathrm{NaHCO}_{3}$, and $20 \mathrm{mg} / \mathrm{L}$ of ethylene glycol tetraacetic acid (EGTA). While in this solution, the liver samples were cut into very small pieces, and cleared of blood and rude tissue components, such as vessels and connective tissue. Then, the liver was minced into pieces and mechanically dissociated into further small pieces using fine forceps and surgical blades. This process was repeated and continued, all while the samples were in the clear solution-I. Next, the whitened pieces of tissue were transferred into solution-II, which possessed the same compounds found in solution-l; however, rather than EGTA, included were $0.11 \mathrm{~g} / \mathrm{L}$ of $\mathrm{CaCl}_{2}$ and $0.025 \mathrm{mg} / \mathrm{mL}$ of Type IV collagenase, to break the $\mathrm{Ca}^{2+}$-dependent cell-cell connections and enzymatic dissociation of the cells. After softening of the tissue pieces in solution-II for $10 \mathrm{~min}$, trituration was performed using different sized pipette tips. The crude particles were removed by means of a stainless-steel sieve and then the obtained cell suspension was passed carefully through a sterilized injector needle for further cell dissociation. The suspension was then transferred into Eppendorf tubes and centrifuged for 3 min at $60 \times g$. The cell pellet was resuspended in Leibovitz 15 (L-15) medium, that comprised 1\% (v/v) antibiotic-antimycotic and $0.38 \mathrm{~g} / \mathrm{L}$ of $\mathrm{NaHCO}_{3}$. After the second wash with $\mathrm{L}-15$, the cells were suspended in the medium. Next, a Thoma slide was used to count the cells, and the Trypan blue exclusion test was used to assess cell viability. For the cell culture studies, observation of the cells was performed to possess more than $90 \%$ viability.

\section{Hepatocyte Culture and BPF Treatment}

The isolated hepatocytes were seeded into 24-well collagen-I coated culture plates (Gibco, Catalogue no: A11428-02, Thermo Fisher Scientific, MA, USA) within $1 \mathrm{~mL}$ of medium that contained a density of $5 \times$ $10^{5}$ cells in each well. A temperature of $14^{\circ} \mathrm{C}$ was used to maintain the cells for $24 \mathrm{~h}$ in a sterile incubator (Binder, Tuttlingen, Germany), under atmospheric air, with saturated humidity, before BPF treatment. A stock solution of $0.1 \mathrm{M}$ of BPF (Sigma-Aldrich, MO, USA; $\mathrm{CH}_{2}\left(\mathrm{C}_{6} \mathrm{H}_{4} \mathrm{OH}\right)_{2}, \mathrm{MW}: 200.23$, analytical standard) was prepared in absolute ethanol and exposure media that contained BPF concentrations of $15.63,31.25$, $62.50,125,250$, and $500 \mu \mathrm{M}$ were applied to the cells for $24 \mathrm{~h}$. The final ethanol concentration did not exceed $0.5 \%$ in the media. Cells in the control group received L-15 medium that contained only $0.5 \%$ absolute ethanol. For the experimental groups, 5 replicate wells were constructed. The cell cultures were examined using a Leica DMI 6100B inverted microscope (Wetzlar, Germany).

\section{Lactate Dehydrogenase Cytotoxicity Test}


Measurement of the lactate dehydrogenase (LDH) leakage into the culture media was used to determine the cytotoxic effects of the BPF after $24 \mathrm{~h}$ of treatment. After completion of the treatments, removal of the culture media samples from the wells was performed, which were then placed into Eppendorf tubes. Next, the samples $(10 \mu \mathrm{L})$ were placed into a 96-well plate and an Abcam LDH-cytotoxicity assay kit (Cambridge, UK; Catalogue no: ab65393) was used to assay the LDH activity, following the manufacturer's instructions. Finally, an ELISA DAS A3 plate reader (Rome, Italy) was used to measure the optic density (OD) values at $450 \mathrm{~nm}$. For each experiment, 5 replicates were performed. All of the measurements were performed in duplicate, and the percentage of cytotoxicity was calculated for each sample using the formula provided in the booklet that came with the kit, as follows:

$$
\text { Cytotoxicity }(\%)=\frac{(\text { OD of test sample }- \text { OD of low control well })}{(\text { OD of high control well }- \text { OD of low control well })} \times 100
$$

\section{Measurement of the Antioxidant Defence Indicators}

Following completion of the exposures, the culture media was gently pipetted out of the wells and $1 \mathrm{~mL}$ of ice-cold phosphate buffered saline, at a pH of 7.4, was used to rinse the hepatocytes. The cell suspensions obtained $\left(1 \times 10^{6} / \mathrm{mL}\right)$ were then placed into Eppendorf tubes and a Jencons glassporcelain ultrasonic homogenizer (Herts, UK) was used to lyse them. Centrifugation of the homogenate was then performed for $15 \mathrm{~min}$ at $20,000 \times \mathrm{g}$. All of the procedures were performed on ice or at $4{ }^{\circ} \mathrm{C}$. Next, the removal of the supernatant fractions was performed and they were then used for the determination of antioxidant defence indicators. For each experiment, 5 replicates were performed.

Measurement of the malondialdehyde (MDA) content, which is the result of lipid peroxidation, was performed at $532 \mathrm{~nm}$, spectrophotometrically, using the method proposed by Jain et al., which was based on thiobarbituric acid reactivity [20]. The results were presented as nmol/5 $\times 10^{5}$ cells. The superoxide dismutase (SOD) activity was performed spectrophotometrically using a Ransel commercial kit (Randox Laboratories Ltd., UK), following the manufacturer's instructions. The activity was presented as unit/ $5 \times$ $10^{5}$ cells. The catalase (CAT) activity was measured spectrophotometrically using the method reported by Aebi [21]. The results were expressed as $\mu$ mole of consumed $\mathrm{H}_{2} \mathrm{O}_{2} / \mathrm{min} / 5 \times 10^{5}$ cells. The reduced glutathione (GSH) content was assayed at $412 \mathrm{~nm}$ spectrophotometrically, according to the method of Beutler [22]. The results were presented as $\mu$ mole $/ 5 \times 10^{5}$ cells. The glutathione peroxidase (GPx) activity was performed using a Ransel commercial kit (Randox Laboratories Ltd.) at $37^{\circ} \mathrm{C}$ and $340 \mathrm{~nm}$, based on the manufacturer's instructions. The results were presented as unit $/ 5 \times 10^{5}$ cells. Measurement of the glutathione S-transferase (GST) was performed using 1-chloro-2,4-dinitrobenzene (CDNB) as a substrate [23]. The activity of the GST was presented as nmol of CDNB-glutathione conjugate/min $/ 5 \times 10^{5}$ cells.

\section{Statistical Analysis}


SPSS Statistics for Windows 20.0 (IBM SPSS Statistics Inc., Chicago, IL, USA) was used to perform the statistical analyses. To analyse the differences among the groups, one-way ANOVA and the Duncan multiple comparison post-hoc test was used. The results were presented as the mean \pm standard deviation (SD). Statistical significance was accepted as $P<0.05$.

\section{Results}

The microscopic examination of the cells after completion of the trials showed that the control hepatocytes formed groups or cord-like arrangements and possessed a healthy appearance (Fig. 1a). The treated hepatocytes displayed degenerative changes and less healthy appearance when compared to the control cells (Fig. 1b).

All of the concentrations of BPA caused significantly increased leakage of the LDH into the media. The percentage of cellular cytotoxicity gradually increased with the BPF concentrations $(P<0.05)$. Cytotoxicity was observed with BPF concentrations of $7.27 \pm 0.99 \%, 12.17 \pm 0.87 \%, 16.58 \pm 1.60 \%, 23.43 \pm 3.39 \%$, $29.39 \pm 2.35 \%$, and $32.55 \pm 2.47 \%$ at $15.63,31.25,62.50,125,250$, and $500 \mu \mathrm{M}$, respectively (Fig. 2).

The MDA content was significantly elevated with BPF concentrations of $15.63,31.25,62.50,125,250$ and $500 \mu \mathrm{M}$; however, while it did not change with $500 \mu \mathrm{M}$ after 24 h-exposure to BPF (Fig. 3a). The hepatocyte SOD activity displayed significant increases $(P<0.05)$ (Fig. $3 b)$, while the CAT activity was reduced significantly $(P<0.05)$ (Fig. 3c) with all of the concentrations of BPF. There were significant increases in the content of GSH with BPF concentrations of $15.63,31.25,62.50,125$, and $250 \mu \mathrm{M}(\mathrm{P}<$ 0.05); however, the GSH contents were significantly decreased with $500 \mu \mathrm{M}$ of BPF $(P<0.05)$ (Fig. 3d). GPx activity was significantly increased with BPF concentration of $31.25,62.50,125,250$ and $500 \mu \mathrm{M}(\mathrm{P}$ $<0.05$ ), while there was no significant change in the $15.63 \mu \mathrm{M}$ concentration (Fig. 3e). GST activity was only significantly increased at the $125 \mu \mathrm{M}$ concentrations of BPF $(P<0.05)$, while it did not change with the other concentrations (Fig. 3f).

\section{Discussion}

The toxic and endocrine potential of BPA have been well-studied; however, knowledge regarding its analogue, BPF, is limited, especially in aquatic organisms. BPF is frequently preferred in the manufacturing of industrial and daily products instead of BPA, and its presence has been widely detected in aquatic compartments. Fish, which are an important part of the food chain, are at risk of exposure to environmental chemicals via their surrounding environment, and thus, it is necessary to investigate and elucidate the toxic impacts of BPF and its underlying mechanisms in fish. With this aim, first investigated herein were the antioxidant indicators in primary cultured rainbow trout hepatocytes that had been treated with BPF for $24 \mathrm{~h}$.

The LDH cytotoxicity test demonstrated that BPF exposure affected the cells in a dose-dependent manner and the percentage of cytotoxicity was observed to be 32.55 with the highest concentration of BPF. 
Several studies of different cell types have reported that BPF-induced cytotoxicity increased with increased concentrations and treatment times. For example, cytotoxicity was increased on a dosedependent basis in human cell lines (HCLs), such as hepatoma HCL, HepG2; intestinal HCL, LS174T; and renal $\mathrm{HCL}, \mathrm{ACHN}$, treated with BPF concentrations ranging from 5 to $100 \mu \mathrm{M}$ for $24 \mathrm{~h}$ [24]. Similarly, BPFinduced cytotoxicity was reported with concentrations of $0-600 \mu \mathrm{M}$ for $24 \mathrm{~h}$ in RWPE-1 cells [16]. Russo et al. reported that mouse embryo fibroblast cells and cancer cells exposed to BPF ( $0-300 \mu \mathrm{M}$ for $48 \mathrm{~h}$ ) resulted in increased cytotoxicity in a dose-dependent manner [25]. Jambor et al. [26] also determined escalated cytotoxic activity in mouse TM3 Leydig cells treated with BPF concentrations of $10-50 \mu \mathrm{g} / \mathrm{mL}$ for $24 \mathrm{~h}$. On the other hand, BPF did not induce cytotoxicity, even at a concentration of $200 \mu \mathrm{M}$ for $24 \mathrm{~h}$, in the human adrenal carcinoma cell line (H295R), but was found to be cytotoxic at concentrations of 300 and $500 \mu \mathrm{M}$ [27]. No significant changes in cell viability were observed in the human hepatoma cell line (HepG2) exposed to BPF concentrations of 12.5-100 $\mu \mathrm{mol} / \mathrm{L}$ for $24 \mathrm{~h}$ [28]. Moreover, Hercog et al. [6] reported that no significant variations were observed in the viability of human hepatoma cells (HepG2) with BPF concentrations of 2.5 and $20 \mu \mathrm{g} / \mathrm{mL}$ for $24 \mathrm{~h}$, while they determined significantly decreased cell viability at the highest BPF concentration for $72 \mathrm{~h}$. Thus, the similar or different findings regarding the cytotoxic impact of BPF on cells from past studies to the current study might have resulted from the cell type used, experimental design, treatment time, or selected assays for the determination of cytotoxicity.

MDA is an end-product of lipid peroxidation and a commonly used assay for monitoring membrane damage or oxidative stress [14]. It has been reported that BPF enhances ROS levels and leads to increased levels of lipid peroxidation in human erythrocytes [15]. In another study, BPF resulted in a high level of MDA contents and finally led to apoptosis in the larvae of zebrafish [7]. Ullah et al. [5] also reported increased levels of lipid peroxidation and ROS in the reproductive tissues of male rats after exposure to BPF. Consistent with these studies, the MDA content was significantly increased in the hepatocytes in the current study, suggesting that BPF is capable of disrupting cell membranes; however, the MDA content remained unchanged or dropped to a level similar to that of the control, even with the highest concentration of BPF. Although the exact mechanism underlying such an effect is unclear, some toxicity studies have reported results similar to those observed in the present study. For example, even though Liu et al. [29] did not observe a significant change in the MDA contents in the cultured hepatocytes of freshwater tilapia (Orechromis niloticus) after 24-h exposure to perfluorooctane sulfonate, an increased ROS level was determined. In another study, MDA levels showed significantly increased levels with lower BPF concentrations, whereas no significant changes were observed with higher concentrations in the liver of carp (Cyprinus carpio) exposed to diethyl phthalate for 2 days [30]. Similar trends in the MDA content were also found in carp [31], and juvenile and adult Daphnia magna exposed to phthalate esters and di-(2-ethylhexyl) phthalate [32], respectively. As a result of these observations, two opinions have been put forth. The first was that exposure to a low concentration of the chemical initiated a quick increase in ROS, which damaged the lipids, and then the organisms counteracted a ROS attack via the antioxidant system or by eliminating the damaged lipids [14,31]. The second was that membrane integrity was disrupted by the harmful chemical, due to the impairment of cellular lipid metabolism and alterations in the plasma phospholipid composition, and finally, the MDA content was decreased [32, 33]. 
The current study results showed that 24-h exposure of the isolated hepatocytes to BPF affected enzymatic scavengers, including SOD, CAT, GPx, and GST, which were also utilized as biomarkers for a study of environmental toxicity in fish by van der Oost et al. [34]. CAT and SOD act as the first-line of defence against attacks by ROS in cells. Dismutation superoxide anion radicals are catalysed by SOD into hydrogen peroxide and molecular oxygen. In the present study, SOD activities were significantly increased with all of the BPF concentrations when compared to the control group, presumably in response to enhanced cellular superoxide anion radicals. In accordance with the present study, in vitro studies using fish hepatocytes have also reported increased SOD activities after exposure to different types of environmental chemicals, such as BPA [35], perfluorinated organic compounds [29], di(2ethylhexyl) phthalate [36], and benzo[a]pyrene and nonylphenol [37]. On the other hand, no significant changes were seen in the SOD activity of juvenile common carp liver (Cyprinus carpio) samples after long-term (60 days) waterborne exposure to BPF [38]. Conversely, Gu et al. [7] stated decreased SOD activities in the larvae of zebrafish treated with BPF concentrations of $7-700 \mu \mathrm{g} / \mathrm{L}$ for 3 and 6 days. It can be said that the different findings regarding the SOD activities as a consequence of BPF exposure might have depended on the applied BPF concentration, and design and duration of the experiment. CAT degrades hydrogen peroxide, a hydroxyl radical precursor that results from SOD activity, into water and oxygen and protects unsaturated fatty acids on the cell membrane from peroxidation [14]. In the current study, exposure of hepatocytes to BPF resulted in significantly decreased CAT activity. Similar to these findings, Maćczak et al. found decreased levels of CAT in human erythrocytes treated with BPF for different periods of time (4 $\mathrm{h}$ and $24 \mathrm{~h}$ ) [15]. Decreased CAT activity was also found in juvenile common carp [37], and the larvae of zebrafish after waterborne exposure to BPF [7]. Ullah et al., also reported that CAT activity was inhibited in the testicular tissues of rats exposed to BPF via drinking water [5]. Modesto and Martinez reported that many antioxidant enzymes might be inactivated by an excessive increase in oxidants or the substrate of the enzyme could be an oxidant [39]. Thus, the decreased CAT activity could be explained by accelerated SOD activity as a consequence of the excessive production of superoxide anion radicals, which then lead to higher intracellular hydrogen peroxide generation [40, 41]. In accordance with the results herein, decreased CAT activity with increased SOD activity have been also found in the liver of goldfish (Carassius auratus) exposed to subacute concentrations of nickel [42], and liver samples of Nile tilapia (Oreochromis niloticus) collected from polluted waters [43].

$\mathrm{GSH}$, a tripeptide that contains cysteine, $g$-glutamine, and glycine, is an antioxidant molecule that directly metabolizes and detoxifies xenobiotics that conjugate directly, in addition to protecting cells from oxidative damage. Both increases and decreases of the molecule are indicative of oxidative stress [44]. GSH levels in this study were observed to be increase in the hepatocytes with concentrations that ranged between 15.63 and $250 \mu \mathrm{M}$; however, a significant decrease in the GSH content was determined with $500 \mu \mathrm{M}$ of BPF. Similar to the results herein, Kose et al. reported elevated GSH levels in RWPE-1 cells that were treated with BPA, as well as its analogues, BPF and BPS, for $24 \mathrm{~h}$ [16]. In another study, Maćczak et al. [15] found depleted GSH levels in human erythrocytes exposed to BPF. GSH levels might increase under slight oxidative stress, as an adaptive mechanism to counteract ROS attacks; however, severe oxidative stress could lead to the depletion of the GSH contents as a consequence of the disruption of 
adaptive mechanisms [45]. Thus, the decrease in the GSH level with $500 \mu \mathrm{M}$ of BPF was probably due to the severity of the oxidative stress that occurred with such a high concentration.

GPx activity was found to increase remarkably with all of the BPF concentrations, with the exception of $15 \mu \mathrm{M}$. GPx is an antioxidant scavenging enzyme that catalyses the degradation of hydroperoxides into hydroxyl compounds, utilizing GSH as a cofactor. The activity of GPx is closely related with its cofactor, $\mathrm{GSH}$, and a reduction of the molecule might cause a decrease in the activity of the enzyme in cells [46]. Thus, a probable increase in the levels of lipid hydroperoxydes and hydroxyperoxides in the hepatocytes after BPF exposure could lead higher GPx activities, in an attempt to cope with the oxidative insult of the BPF. In parallel with the literature knowledge, synchronized increases in GPx activity with GSH levels were observed in the current study; however, an unchanged or decreased level of the enzyme did not occur, even though a significant drop was detected in the GSH level with the highest concentration of BPF. The unaffected levels of GPx activity at this concentration may have resulted because, even if a decrease in the GSH pool occurred with this concentration, the level of GSH was still adequate for the utilization of the enzyme. In support of this explanation, decreases in GSH levels were observed in human erythrocytes with minimal exposure to BPF ( $4 \mathrm{~h}$ ), while decreased activities of GPx appeared after $24 \mathrm{~h}$ of exposure, depending on the BPF concentration applied [14].

GST is a Phase-Il detoxifying enzyme that has a critical role in cellular protection against ROS and toxic xenobiotics. GST catalyses GSH conjugation in reaction to endogenous and exogenous electrophiles [47]. In the study herein, significantly increased GST activity was observed with $125 \mu \mathrm{M}$ of BPF, while it remained unchanged with the other concentrations. Previous studies performed in both the laboratory and field have displayed that exposure to environmental chemicals that possess endocrine-disrupting potential induced GST activity in the liver of fish; however, unchanged or reduced GST activities were also reported $[34,48,49]$. Due to the lack of research regarding the impact of BPF on liver GST activity, it was not possible to compare the results determined herein. On the other hand, similar to the findings of the current study, in a recent study, GST activity was induced in marine rotifer (Brachionus koreanus) after 24h exposure to BPF [50].

\section{Conclusion}

Overall, it was observed that BPF could cause oxidative damage and lead to antioxidant responses in the isolated hepatocytes of rainbow trout. According to the results, BPF, which has been environmentally detected in aquatic environments and fish tissues, did not seem to be a safe alternative for BPA. Thus, authorities should take measures to prevent BPF contamination in aquatic environments and reconsider the status of BPF as a safe alternative. The present data will also offer new insight regarding the toxic impact mechanism of BPF, which are poorly understood in fish species.

\section{Declarations}

\section{Author Contributions}


BK conceived the research. HA and BK contributed in isolation of the hepatocytes, hepatocyte culture and treatments. HA and BK performed the cytotoxicity test and measurement of antioxidant defense system indicators. BK performed the analyzed the data and interpreted the results. BK drafted, edited and finalized the manuscript.

\section{Funding}

The Scientific Research Coordination Unit of Van Yuzuncu Yil University supported this work under project number: FYL-2020-8807.

\section{Compliance with Ethical Standards}

Ethical approval The procedures conducted herein were in line with those of the National and Institutional Regulations for the Protection of Animal Welfare. This study received ethical approval by The Animal Experiments Ethics Committee of Van Yuzuncu Yil University (decision number: 2020/06-19, protocol number: E.43066).

Conflict of Interest The authors declare that there are no conflicts of interest.

\section{Data availability}

The data and material used and analyzed during the current study are available from the corresponding author on reasonable request.

\section{References}

1. Rochester JR, Bolden, AL (2015) Bisphenol S and F: a systematic review and comparison of the hormonal activity of bisphenol A substitutes. Environ Health Perspect 123(7):643-650. https://doi.org/10.1289/ehp.1408989

2. Liao C, Kannan K (2013) Concentrations and profiles of bisphenol A and other bisphenol analogues in foodstuffs from the United States and their implications for human exposure. J Agric Food Chem 61(19):4655-4662. https://doi.org/10.1021/jf400445n

3. Liao C, Liu F, Guo Y, Moon, HB, Nakata H, Wu Q, Kannan K (2012) Occurrence of eight bisphenol analogues in indoor dust from the United States and several Asian countries: implications for human exposure. Environ Sci Technol 46(6):9138-9145. https://doi.org/10.1021/es302004w

4. Fromme H, Küchler T, Otto T, Pilz K, Müller J, Wenzel A (2002) Occurrence of phthalates and bisphenol $A$ and $F$ in the environment. Water Res 36(6):1429-1438. https://doi.org/10.1016/s00431354(01)00367-0

5. Ullah A, Pirzada M, Afsar T, Razak S, Almajwal A, Jahan S (2019) Effect of bisphenol F, an analog of bisphenol A, on the reproductive functions of male rats. Environ Health Prev Med 24(1):41. https://doi.org/10.1186/s12199-019-0797-5 
6. Hercog K, Maisanaba S, Filipič M, Sollner-Dolenc M, Kač L, Žegura B (2019) Genotoxic activity of bisphenol $\mathrm{A}$ and its analogues bisphenol $\mathrm{S}$, bisphenol $\mathrm{F}$ and bisphenol $\mathrm{AF}$ and their mixtures in human hepatocellular carcinoma (HepG2) cells. Sci Total Environ 687:267-276. https://doi.org/10.1016/j.scitotenv.2019.05.486

7. Gu J, Wu J, Xu S, Zhang L, Fan D, Shi L, Wang J, Ji G (2020) Bisphenol F exposure impairs neurodevelopment in zebrafish larvae (Danio rerio). Ecotoxicol Environ Saf 188: https://doi.org/10.1016/j.ecoenv.2019.109870

8. Shi M, Lin Z, Ye L, Chen X, Zhang W, Zhang Z, Luo F, Liu Y, Shi M (2020) Estrogen receptor-regulated SOCS3 modulation via JAK2/STAT3 pathway is involved in BPF-induced M1 polarization of macrophages. Toxicol 433:152404. https://doi.org/10.1016/j.tox.2020.152404

9. Barboza LGA., Cunha SC, Monteiro C, Fernandes JO, Guilhermino L (2020) Bisphenol A and its analogs in muscle and liver of fish from the North East Atlantic Ocean in relation to microplastic contamination. Exposure and risk to human consumers. J Hazard Mater 393:22419. https://doi.org/10.1016/j.jhazmat.2020.122419

10. Yang Q, Yang X, Liu J, Ren W, Chen Y, Shen S (2017) Effects of BPF on steroid hormone homeostasis and gene expression in the hypothalamic-pituitary-gonadal axis of zebrafish. Environ Sci Pollut Res 24(26):21311-21322. https://doi.org/10.1007/s11356-017-9773-z

11. Mu X, Liu J, Yuan L, Yang K, Huang Y, Wang C, Yang W, Shen G, Li Y (2019) The mechanisms underlying the developmental effects of bisphenol F on zebrafish. Sci Total Environ 687:877-884. https://doi.org/10.1016/j.scitotenv.2019.05.489

12. Huang GM, Tian, XF, Fang XD, Ji FJ. (2016) Waterborne exposure to bisphenol F causes thyroid endocrine disruption in zebrafish larvae. Chemosphere 147:188-194.

https://doi.org/10.1016/j.chemosphere.2015.12.080

13. Al-Gubory KH (2014) Environmental pollutants and lifestyle factors induce oxidative stress and poor prenatal development. Reprod Biomed Online 29(1):17-31.

https://doi.org/10.1016/j.rbmo.2014.03.002

14. Lushchak VI (2011) Environmentally induced oxidative stress in aquatic animals. Aquat Toxicol 101(1):13-30. https://doi.org/10.1016/j.aquatox.2010.10.006

15. Maćczak A, Cyrkler M, Bukowska B, Michałowicz J (2017) Bisphenol A, bisphenol S, bisphenol F and bisphenol AF induce different oxidative stress and damage in human red blood cells (in vitro study). Toxicol In Vitro 41:143-149. https://doi.org/10.1016/j.tiv.2017.02.018

16. Kose O, Rachidi W, Beal D, Erkekoglu P, Fayyad-Kazan H, Kocer Gumusel B (2020) The effects of different bisphenol derivatives on oxidative stress, DNA damage and DNA repair in RWPE-1 cells: A comparative study. J Appl Toxicol 40(5):643-654. https://doi.org/10.1002/jat.3934

17. Bols NC, Dayeh VR, Lee LEJ, Schirmer K (2005) Use of fish cell lines in the toxicology and ecotoxicology of fish. piscine cell lines in environmental toxicology. In: Mommsen TP, Moon TW (eds) Biochemistry and Molecular Biology of Fishes, Elsevier BV vol 6 pp 43-84. https://doi.org/10.1016/S1873-0140(05)80005-0 
18. OECD (2019). Test no. 203: fish, acute toxicity test. OECD guidelines for the testing of chemicals, section 2. OECD Publishing, Paris. https://doi.org/10.1787/9789264069961-en.

19. Mortensen AS, Tolfsen CC, Arukwe A (2006) Gene expression patterns in estrogen (nonylphenol) and aryl hydrocarbon receptor agonists (PCB-77) interaction using rainbow trout (Oncorhynchus mykiss) primary hepatocyte culture. J Toxicol Environ Health 69(1-2):1-19.

https://doi.org/10.1080/15287390500257792

20. Jain SK, McVie R, Duett J, Herbst JJ (1989) Erythrocyte membrane lipid peroxidation and glycolylated hemoglobin in diabetes. Diabetes 38(12):1539-1543. https://doi.org/10.2337/diab.38.12.1539

21. Aebi H (1974) Catalase. In: Bergemeyer HU (ed). Methods of enzymatic analysis. Academic Press, New York, pp 673-684

22. Beutler E (1984) Red cell metabolism. In: A manual of biochemical methods, 3rd edn. Grune and Startton, New York, pp 105-106

23. Habig WH, Pabst MJ, Jakoby WB (1974) Glutathione S-transferases. The first enzymatic step in mercapturic acid formation. J Biol Chem 249:7130-7139

24. Audebert M, Dolo L, Perdu E, Cravedi JP, Zalko D (2011) Use of the $\mathrm{H} H 2 A X$ assay for assessing the genotoxicity of bisphenol A and bisphenol $F$ in human cell lines. Arch Toxicol 85:1463-1473. https://doi.org/10.1007/s00204-011-0721-2

25. Russo G, Capuozzo A, Barbato F, Irace C, Santamaria R, Grumetto L (2018) Cytotoxicity of seven bisphenol analogues compared to bisphenol $\mathrm{A}$ and relationships with membrane affinity data. Chemosphere 201:432-440. https://doi.org/10.1016/j.chemosphere.2018.03.014

26. Jambor T, Kovacikova E, Greifova H, Kovacik A, Libova L, Lukac N (2019) Assessment of the effective impact of bisphenols on mitochondrial activity and steroidogenesis in a dose-dependency in mice TM3 Leydig cells. Physiol Res 68(4):689-693. https://doi.org/10.33549/physiolres.934200

27. Feng Y, Jiao Z, Shi J, Li M, Guo Q, Shao B (2016) Effects of bisphenol analogues on steroidogenic gene expression and hormone synthesis in H295R cells. Chemosphere 147:9-19 https://doi.org/10.1016/j.chemosphere.2015.12.081

28. Fic A, Zegura B, Dolenc MS, Filipic M, Masic LP (2013) Mutagenicity and DNA damage of bisphenol A and its structural analogues in HepG2 cells. Arh Hig Rada Toksikol 64(2):189-200. https://doi.org/10.2478/10004-1254-64-2013-2319

29. Liu C, Yu K, Shi X, Wang J, Lam PK, Wu RS, Zhou B (2007) Induction of oxidative stress and apoptosis by PFOS and PFOA in primary cultured hepatocytes of freshwater tilapia (Oreochromis niloticus). Aquat Toxicol 82(2):135-143. https://doi.org/10.1016/j.aquatox.2007.02.006

30. Zhang G (2015) Effect of diethyl phthalate on biochemical indicators of carp liver tissue. Toxin Rev 34(1):21-27. https://doi.org/10.3109/15569543.2014.958758

31. Zhao X, Gao Y, Qi M (2014) Toxicity of phthalate esters exposure to carp (Cyprinus carpio) and antioxidant response by biomarker. Ecotoxicol 23(4):626-632 https://doi.org/10.1007/s10646-014$1194-x$ 
32. Wang Y, Wang T, Ban Y, Shen C, Shen Q, Chai X, Zhao W, Wei J (2018) Di-(2-ethylhexyl) phthalate exposure modulates antioxidant enzyme activity and gene expression in juvenile and adult Daphnia magna. Arch Environ Contam Toxicol 75(1):145-156 https://doi.org/10.1007/s00244-018-0535-9

33. Lin CY, Chen PC, Hsieh CJ, Chen CY, Hu A, Sung FC, Lee HL, Su TC (2017) Positive association between urinary concentration of phthalate metabolites and oxidation of DNA and lipid in adolescents and young adults. Sci Rep 7:44318. https://doi.org/10.1038/srep44318

34. van der Oost R, Beyer J, Vermeulen NPE (2003) Fish bioaccumulation and biomarkers in environmental risk assessment: a review. Environ Toxicol Pharmacol 13(2):57-149. https://doi.org/10.1016/s1382-6689(02)00126-6

35. Kaya Ö, Kaptaner B (2016) Antioxidant defense system parameters in isolated fish hepatocytes exposed to bisphenol A- effect of vitamin C. Acta Biol Hung 67(3):225-235. https://doi.org/10.1556/018.67.2016.3.1

36. Kaptaner GC, Bati B, Kaptaner B (2020) Antioxidant responses in the cytotoxicity of isolated rainbow trout (Oncorhyncus mykiss) hepatocytes induced by di(2-ethylhexyl) phthalate. Fresen Environ Bull 29(6):4364-4371

37. Salamat N, Derakhshesh N (2020) Oxidative stress in liver cell culture from mullet, Liza klunzingeri, induced by short-term exposure to benzo[a]pyrene and nonylphenol. Fish Physiol Biochem 46(4):1183-1197. https://doi.org/10.1007/s10695-020-00783-y

38. Qiu W, Zhan H, Tian Y, Zhang, T, He X, Luo S, Xu H, Zheng C (2018) The in vivo action of chronic bisphenol $\mathrm{F}$ showing potential immune disturbance in juvenile common carp (Cyprinus carpio). Chemosphere 205:506-513. https://doi.org/10.1016/j.chemosphere.2018.04.105

39. Modesto KA, Martinez CB (2010) Roundup ${ }^{\circledR}$ causes oxidative stress in liver and inhibits acetylcholinesterase in muscle and brain of the fish Prochilodus lineatus. Chemosphere 78:294-299. https://doi.org/10.1016/j.chemosphere.2009.10.047

40. Pigeolet E, Corbisier P, Houbion A, Lambert D, Michiels C, Raes M, Zachary MD, Remacle J (1990) Glutathione peroxidase, superoxide dismutase, and catalase inactivation by peroxides and oxygen derived free radicals. Mech Ageing Dev 51(3):283-297. https://doi.org/10.1016/00476374(90)90078-t

41. Ezz HSA, Khadrawy YA, Mourad IM (2015) The effect of bisphenol A on some oxidative stress parameters and acetylcholinesterase activity in the heart of male albino rats. Cytotechnology 67(1):145-155. https://doi.org/10.1007/s10616-013-9672-1

42. Rahimikia E (2017) Analysis of antioxidants and serum biochemical responses in goldfish under nickel exposure by sub-chronic test. J Appl Anim Res 45(1):320-325. https://doi.org/10.1080/09712119.2016.1190732

43. Bainy AC, Saito E, Carvalho PS, Junqueira VB (1996) Oxidative stress in gill, erythrocytes, liver and kidney of Nile tilapia (Oreochromis niloticus) from a polluted site. Aquat Toxicol 34(2):151-162. https://doi.org/10.1016/0166-445X(95)00036-4 
44. Stephensen E, Sturve J, Forlin L (2002) Effects of redox cycling compounds on glutathione content and activity of glutathione-related enzymes in rainbow trout liver. Comp Biochem Physiol C: Toxicol Pharmacol 133(3):435-442. https://doi.org/10.1016/s1532-0456(02)00129-1

45. Monteiro DA, De Almeida JA, Rantin FT, Kalinin AL (2006) Oxidative stress biomarkers in the freshwater characid fish, Brycon cephalus, exposed to organophosphorus insecticide Folisuper 600 (methyl parathion). Comp Biochem Physiol C: Toxicol Pharmacol 143(2):141-149. https://doi.org/10.1016/j.cbpc.2006.01.004

46. Łukaszewicz-Hussain A (2003) The role of glutathione and glutathione-related enzymes in antioxidative processes. Med Pr 54:473-479.

47. Li X (2009) Glutathione and glutathione-S-transferase in detoxification mechanisms. In: Ballantyne B, Marrs TC, Syversen T (eds) General and applied toxicology, 2nd edn. John Wiley \& Sons, Chichester, pp 411-423.

48. Otto DME, Moon TW (1996) Phase I and II enzymes and antioxidant responses in different tissues of brown bullheads from relatively polluted and non-polluted systems. Arch Environ Contam Toxicol 31(1):141-147. https://doi.org/10.1007/BF00203918

49. Lu GH, Wang C, Zhu Z (2009) The dose-response relationships for EROD and GST induced by polyaromatic hydrocarbons in Carassius auratus. Bull Environ Contam Toxicol 82(2):194-199. https://doi.org/10.1007/s00128-008-9622-3

50. Park JC, Lee MC, Yoon DS, Han J, Kim M, Hwang U-K, Jung J-H, Lee J-S (2018) Effects of bisphenol $A$ and its analogs bisphenol $\mathrm{F}$ and $\mathrm{S}$ on life parameters, antioxidant system, and response of defensome in the marine rotifer Brachionus koreanus. Aquat Toxicol 199:21-29. https://doi.org/10.1016/j.aquatox.2018.03.024

\section{Figures}



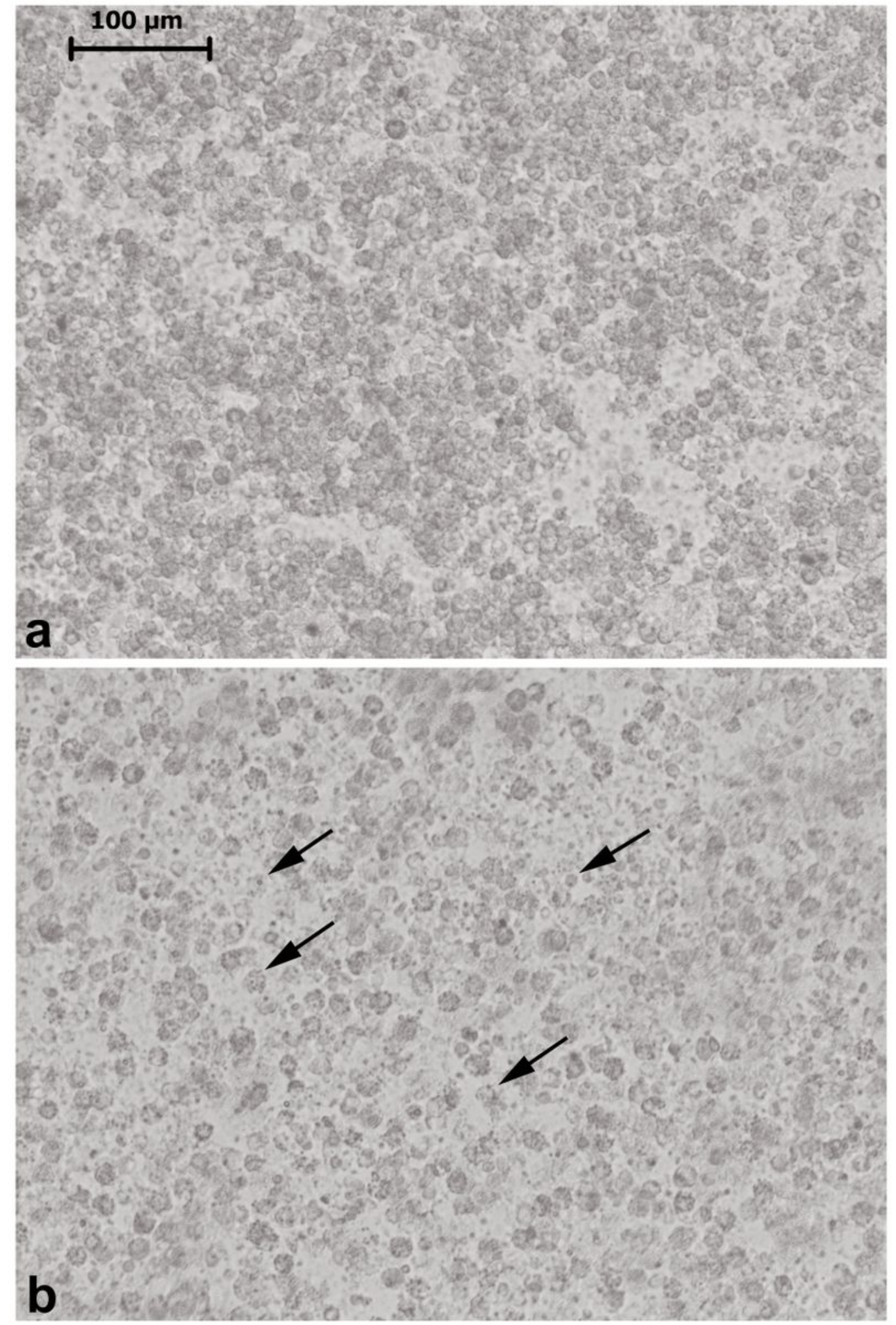

\section{Figure 1}

Representative photomicrographs of the cultured hepatocytes of rainbow trout. A: healthy control cells forming groups. B: Cells exposed to $500 \mu \mathrm{M}$ of BPF for $24 \mathrm{~h}$ that displaying degenerative changes (arrows). 


\section{LDH}

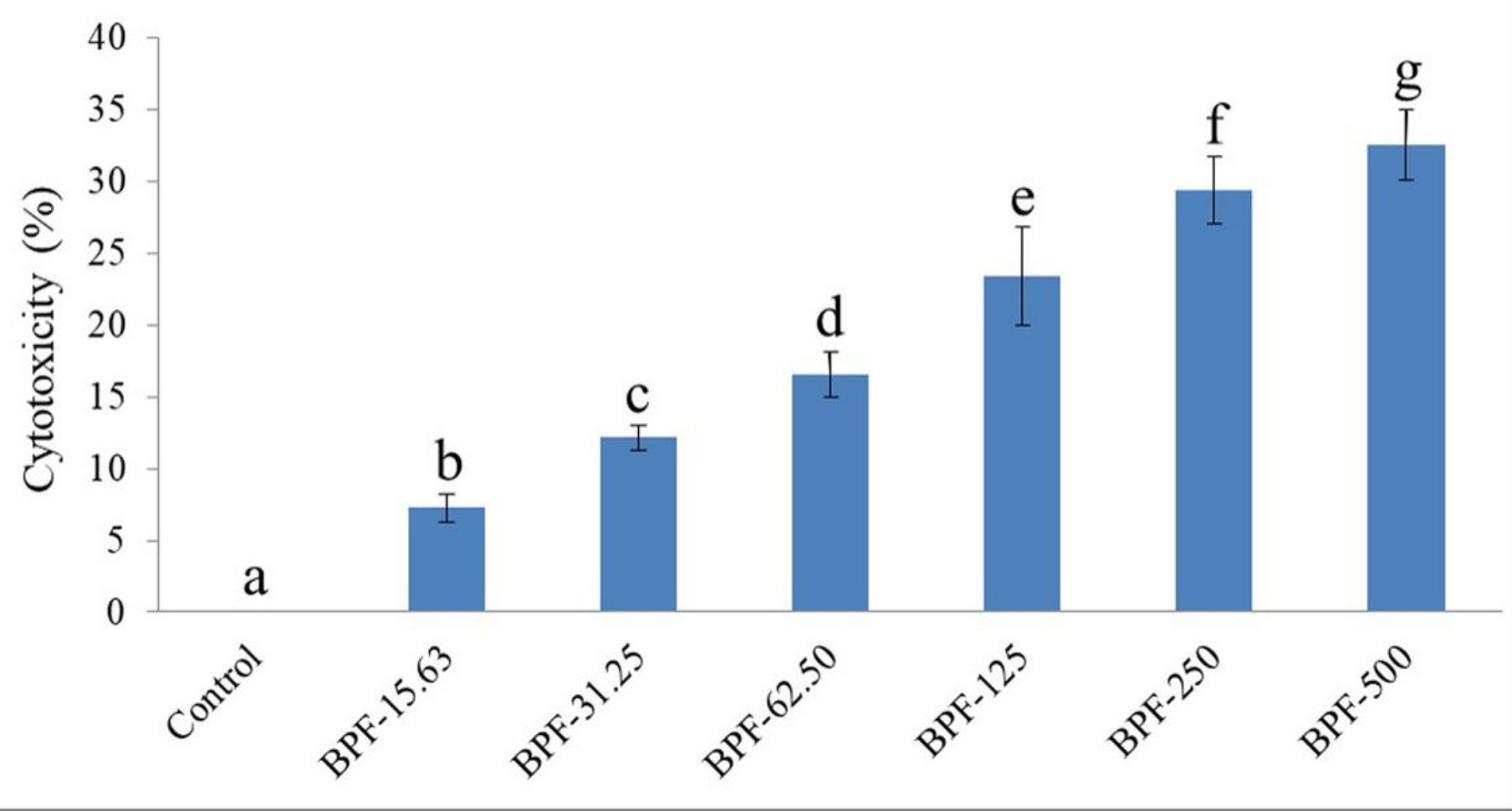

Figure 2

Cytotoxic effect of various concentrations of BPF on the cultured hepatocytes of rainbow trout after $24 \mathrm{~h}$ of exposure. Statistically significant differences between the columns are indicated by different letters. 

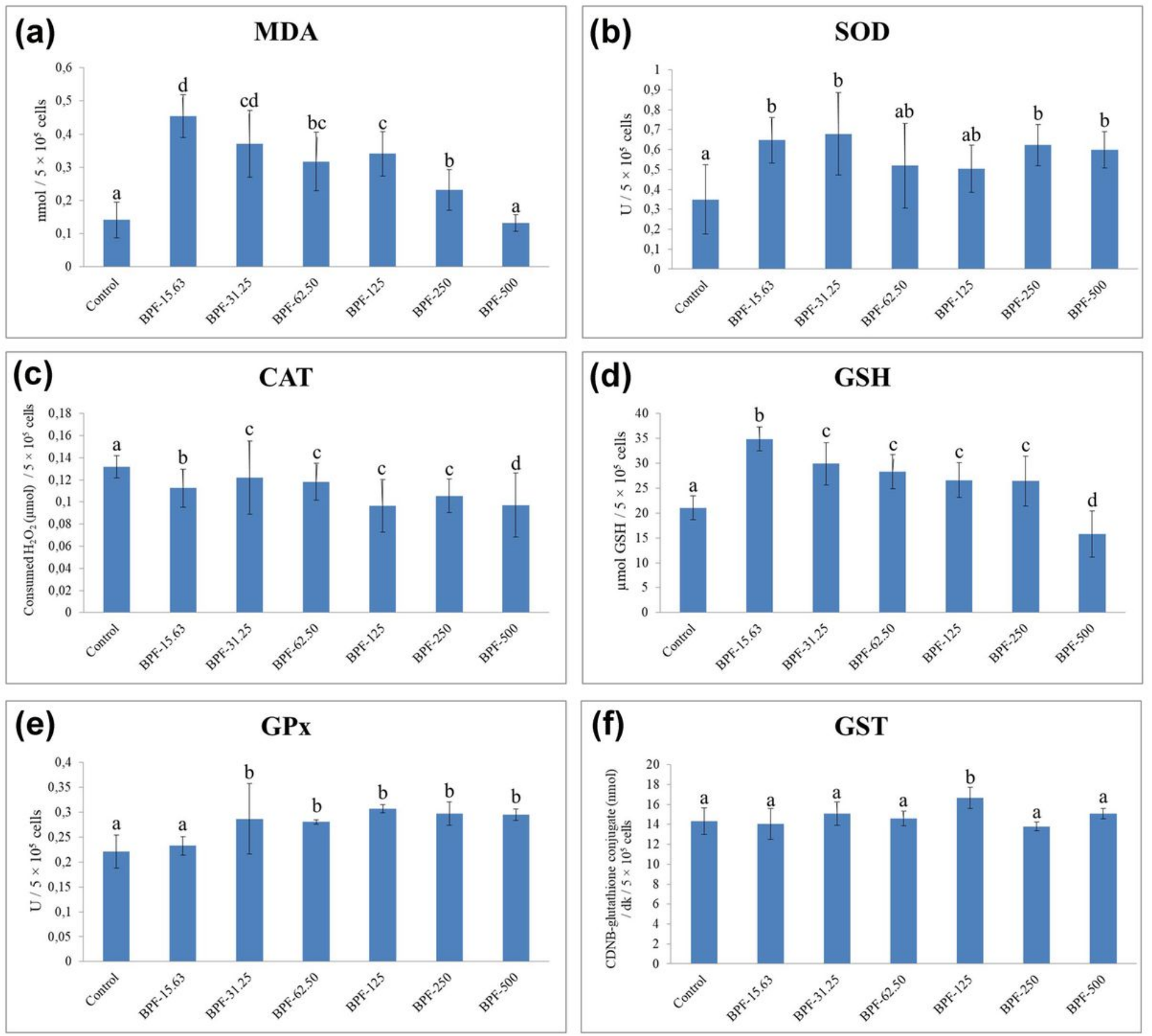

Figure 3

In vitro effects of various concentrations of BPF on the MDA contents (A); SOD (B) and CAT (C) activity; GSH contents (D); and GPx (E) and GST (F) activity. Statistically significant differences between the columns are indicated by different letters. 